\title{
Creativity in Education: Teaching for Creativity Development
}

\author{
Danielle E. Kaplan \\ California School of Education, Alliant International University, San Francisco, United States of America \\ Email: dkaplan@alliant.edu
}

How to cite this paper: Kaplan, D. E. (2019). Creativity in Education: Teaching for Creativity Development. Psychology, 10, 140-147. https://doi.org/10.4236/psych.2019.102012

Received: December 20, 2018

Accepted: January 29, 2019

Published: February 1, 2019

Copyright $\odot 2019$ by author(s) and Scientific Research Publishing Inc. This work is licensed under the Creative Commons Attribution International License (CC BY 4.0).

http://creativecommons.org/licenses/by/4.0/

\begin{abstract}
Creativity is essential to innovation, novelty, and sustenance. This research involves the study of creativity in education, specifically through the training of teachers and future teachers to apply theories of creativity in instructional design. Teacher Education students were exposed to creativity theory and conditioned to apply theory in developing learner creativity in lesson and project design. Creativity theories were included in an online course in cognition and critical thinking in education as foundational psychological frameworks to apply in educational practice and in the design of creative activity in the course. Participants studied and applied creativity frameworks in instruction and learning design in the form of lessons and projects. Lesson Designs were full-length lessons with applications of creativity theory. Project Designs were group projects incorporating creativity theory into an educational resource. Uses of creativity theory in lessons and projects were analyzed for understanding and application of theory.
\end{abstract}

\section{Keywords}

Creativity, Instructional Design, Teacher Training, Online Education

\section{Introduction}

Creativity is necessary to inventive thinking in any domain, and underappreciated in many formal educational environments. All solution making and construction require creative thinking. Yet, almost no schools teach for creativity or train teachers to teach for creativity. The following study explores the value of creativity in educational design in teacher training, and is part of a sequence of studies investigating critical thinking in education. The research was embedded in an online course in critical thinking in teaching and learning in a California school of education. Creativity theories were examined for their utility in educa- 
tion and applied in the design of creation activities integrated into the course. A previous paper (Kaplan, 2017) describes the course. Included in the course were frameworks guiding design, critical thinking content, construction based assignments intended to engage use of theory in design, and collaborative communication. Course skill and learning outcomes include critiquing creativity theories in teaching and learning and applying theories in education.

While there are incredible signs of remarkable creation, there is also evidence everywhere we are in need of creativity development. It has been suggested there is a crisis in creativity thinking, with a decrease in creativity thinking scores (Kim, 2011), suggesting a need for creativity in education. There has been much discourse over creativity in educational institutions internationally (Hall, 2010; Wise \& Ferrara, 2015). Sternberg, 1996, 2006, Sternberg \& Grigorenko, 2003, discuss the nature of creativity and its importance in intelligence. Jausovec and Jausovec (2011) examine the brain and creativity in education. Creativity theorists have advocated for teaching for creativity at all levels of education and training (Werry, 1949; Antonietti, Colombo, \& Pizzingrilli, 2011; Griffiths, 2014; Shaheen, 2010; Brundrett, 2007), including in the design of educational learning environments (Davies, Jindal-Snape, Collier, Digby, Hay, \& Howe, 2013; Richardson \& Mishra, 2018). Lindstrom (2006) questions and considers how we can assess creativity. Craft (2001) and Spendlove (2008) offer reviews of a range of creativity and education advocacies and projects, and Scott, Leritz and Mumford (2004) provide a review of the effectiveness of its training.

The overarching objective of this research is to encourage and evaluate creativity in education, specifically through the training of teachers and educators to incorporate creativity in the practice of developing learners and learning environments. A further objective is to develop the online instructional technologies to support creativity development. This paper describes the participants, instruments and procedure, analysis and results of applying creativity in education in teacher training.

\section{Design}

\subsection{Participants}

Participants were students enrolled in online critical thinking in teaching and learning courses at a California school of education over the course of several Terms. Twenty-one of sixty students volunteered to include their work in the study, five male and 16 female. The participant body was composed of teachers and teachers in training of multiple ethnicities on intern and student teaching tracks in special education, single subject in varying subject areas, multiple subject credentials, and Teaching English as a Second Language (TESOL). Participants included two Multiple Subject candidates, fourteen Single Subject candidates including two in Math, two in English, three in Physical Education, two in Science, two in Language, two Educational Specialists, two undeclared, and one TESOL candidate. Selection was determined by required participation in the 
course and volunteering for the study. The volunteers were representative of the course participants and teacher candidates in the school.

Table 1. Participant make-up.

\begin{tabular}{l}
\hline \multicolumn{1}{c}{ Participants } \\
\hline 2 Multiple Subject Credential Candidates \\
14 Single Subject Credential Candidates \\
2 Educational Specialists \\
1 TESOL Candidate \\
2 Undeclared
\end{tabular}

Table 1 shows a number count for participant make-up out of 21 volunteers, 16 female and 4 male, from 60 participants

\subsection{Instruments and Procedure}

This study was inside of a sequence of readings and assignments and primarily consisted of two assignments: a weekly module focused on creativity and intelligence in the $7^{\text {th }}$ module of an 8 module term, and a final project incorporating all theory covered throughout the course, including creativity application. The study instruments were part of an online course in critical thinking in an Intelligence and Creativity Module. Instruments included creativity readings and assignments made up of lesson design and project activities. Lesson designs required selection of a topic to teach based upon State Standards with a design incorporating the reading. Project designs were culminating group or individual work incorporating creativity theory into projects.

The weekly module creativity lesson design prompt stated: Select three-to five-insights from the principles of intelligence and creativity. Incorporate these insights into one of the following: Your Psychology \& Cognition Lesson Plan from Week One, A revised Psychology \& Cognition Lesson plan from previous weeks, or a new lesson plan that could be used to support your Unit Plan assignment. Support your lesson plan design with suggestions from the readings this week. Submit your lesson plan to the Intelligence \& Creativity Lesson Plan assignment submission forum by Friday.

The final project design prompt stated: Imagine there is a school-wide goal to integrate critical thinking in teaching and learning in the classroom. Create an instructional website covering a specified unit of instruction for students, administrators, and parents at the grade level(s) of your shared interest, on the topic of your shared interest, incorporating learned theories and applications. Incorporate or provide resources and support for the studied elements in your Unit Plan: Psychology and cognition, Behaviorist theories, Constructivism and Piagetian theories, Vygotsky's and Bruner's theories, Learning theory and social cognitive theory, Cognitive and metacognitive development, Intelligence and creativity. Write a 1200- to 1500 -word paper that describes how each of the above elements was incorporated into your Critical Thinking Unit Plan. Include references to course readings. Create a 2- to 3-minute narrated and animated 
presentation to the school district highlighting the main points of your Critical Thinking Unit Plan and instructional website. Include references to course readings.

Participants completed activities individually and in groups during the course of the week of the module and submitted their assignments online. Project and lesson designs were received through online submissions in digital word or web format. Participant designs were analyzed for content.

\subsection{Analysis}

Student constructions were analyzed for creativity theory understanding and referencing and application of creativity theory in education. Referencing to theory and application of theory in lesson design were counted and analyzed for quality of design. Projects were analyzed for theory referencing and application in project design. Types of application of theory were reviewed in lessons and projects.

\section{Intelligence and Creativity Module}

Creativity research, resources, and assignments were designed into Module 7 of an 8 Module Term. Module 7 is a unit on intelligence, emotional intelligence, and creativity in critical thinking. The goal of the module is to provide an overview of intelligence, emotional intelligence, and creativity theories. Learning objectives include analyzing ideologies of intelligence and determining how to effectively apply the ideologies of intelligence in lesson plans and project designs. The components of all Modules and Module 7 are described in a previous paper (Kaplan, 2017). Module 7 is also described below.

The module is made up of readings, forums, and assignments. Readings include Sternberg and Grigorenko (2003), Goleman (1996), Cherry (2016), Sternberg (1996, 2006), and Gardner (1995). Readings present foundational theories in Intelligence, Emotion, and Creativity. Assignments include brainstorming in project groups over how to incorporate intelligence and creativity theories into project design, researching technology for project, selecting insights from intelligence and creativity theorists and incorporating into lessons designed in previous assignments, and providing meaningful feedback to classmates' lesson designs. The Module 7 lesson prompt is described in the Instrument and Procedure section, as is the final project prompt.

\section{Results}

\subsection{Applications in Lesson Designs}

Participants embedded creativity into lesson designs in a multitude of thoughtful applications. One lesson incorporated a creative activity in the creation of a graph. Another supported creative activity in recognizing and understanding emotion. One design involved analyzing and creating messages in music. One lesson used color to develop spatial intelligence in mathematical thinking. 
Another lesson used of a variety of visuals and manipulatives to grow creative thought. Another lesson focused on building on past skill and knowledge as recommended by Sternberg. A $2^{\text {nd }}$ grade lesson employed open assignments to support creativity. Another participant designed acting out of different types of learning. A lesson on language learning was designed to represent language and culture through a creative artifact.

In a $9^{\text {th }}-12^{\text {th }}$ meiosis mitosis Science lesson, creativity was applied by production and viewing of a video and by including bodily kinesthetic physical acting out of the process with verbal and nonverbal information incorporated. A $4^{\text {th }}$ grade history lesson on WWII and Japanese culture included an option to choose your own adventure through the material. An Algebra lesson was designed for students to work to creatively graph and find creative solutions in $\mathrm{Al}$ gebra. A $6^{\text {th }}$ grade lesson on the number system was designed to support dynamic thinking through collaborative idea exchange and asking questions with more than one way of answering. A $10^{\text {th }}$ grade Algebra lesson encouraged collaborative pair share and independent work building upon past work.

A $9^{\text {th }}-12^{\text {th }}$ grade Physical Education circuit training class supported pursuing ideas that are unknown or out of favor but have potential and persisting in resistance against the grain. Video with visual and audio instruction is employed to creatively present material in an $8^{\text {th }}$ grade Geometry lesson. One lesson in $11^{\text {th }}$ grade literature incorporated learning about issues and concepts that morph or creatively expand thinking such as transcendentalism. A $7^{\text {th }}-8^{\text {th }}$ grade ESL lesson involved creatively learning vowel sounds through music and song. A $9^{\text {th }}-$ $12^{\text {th }}$ grade special education lesson designed a sharing environment to encourage creativity through sharing. A physical education lesson incorporated design of a creative fitness plan.

Table 2. Reference and application of theory in lesson designs.

\begin{tabular}{lc}
\hline & Reference and Application of Theories of Emotional Intelligence \\
\hline $\begin{array}{l}\text { Reference and Application } \\
\text { of Theory in Lesson Designs }\end{array}$ & 21 \\
\hline
\end{tabular}

Table 2 shows a number count for whether Creativity theories were referenced and applied in Lesson Designs out of twenty one participants.

\subsection{Applications in Project Designs}

Participants included creativity in project designs in a range of applications. One project design involved designing a bar graph in a math lesson. A project on decoding messages in the media involved exploration of political activism through media and art. An adjective game for middle school students engaged students in identifying adjectives that describe images. One project on healthy eating asked students to create nutrition labels on healthy food. In a project on world travel, networking, and communication in language learning, creativity is considered in the design by applying Sternberg's suggestion of creativity to be enhanced by bringing past knowledge to new experiences in learning about language food 
and travel online. In a project focused on money investment and banking in $12^{\text {th }}$ Grade economics, creativity is incorporated into activity by including song writing about the economy.

In a unit designed to teach high school students research, independent learning activities activate creativity in pattern observation and analysis. In a project based learning unit to teach parents and teachers about problem based learning, a student unit has students choosing their own adventure and create a presentation of their adventure story. In a project to support students in math test taking and learning, creativity was considered to reduce emotional anxiety by having students create schedules for studying and learning aids. In a project on relationship development intervention with children with autism for teachers, teachers are recommended to consider keeping lessons more open ended with more dynamic thinking with problem solving through varying kinds of scenarios, and experiences and showcasing of more than one way toward a solution with multiple perspectives.

In an emergency in athletic training unit, designed to know how to save an athlete's life, creativity is suggested to be applied by providing information in a different way and new options for student expression. In a unit plan designed for alternative assessment, creativity is considered in encouraging creative assessments with more creative ways to show mastery. In a project on physical fitness, creative intelligence is exercised by encouraging students to create exercise plans.

Table 3. Reference and application of theory in project designs.

\begin{tabular}{lc}
\hline & Reference and Application of Theories of Emotional Intelligence \\
\hline $\begin{array}{l}\text { Reference and Application } \\
\text { of Theory in Project Designs }\end{array}$ & 21 \\
\hline
\end{tabular}

Table 3 shows a number count for whether Creativity theories were referenced and applied in Project Designs out of twenty one participants.

\section{Conclusion}

Creativity is fundamental to human thought development and survival. Creativity theories are important in supporting instruction and learning, and elevation of teacher understanding and learning design. This course was successful in inspiring teacher candidates to analyze and apply creativity theory to instruction. Upon reading theories in creativity, teacher education candidates referenced and applied theories in creative ways to develop creativity in study and learning in lesson designs and final projects. Some applications of creativity theory which arose as beneficial to teaching, included employing open assignments, building upon past knowledge in the development of new experiences, creating and/or investigating an artifact, such as creating study skills resources, presentations, media messages, and cultural artifacts, encouraging dynamic thinking through varying scenarios, showcasing multiple solutions, and considering mind expan- 
sive concepts. The results of this study suggest creativity theories should be included in the teaching of teachers in developing their knowledge and skills needed to shape student development, particularly creativity development. Teacher and teacher candidate designs resulted in inspiring learning circumstances for advancing creative activity and thinking through expansive and transcending ideas and action.

The course was successful in cultivating creativity in educational design. The course developed participant thinking about creativity and participant designs. Participants understood and applied theory in a range of creative designs intended to support creativity. A future study could assign the experience differentially with a control group to make a causal claim about course efficacy. The current study does not measure learning from the creativity design in K-12 students for whom the lessons and projects are designed, though does in course participant creations. Another future study could investigate how the teacher constructed designs influence learning in the classroom. Broader work might consider how creativity training and thought can be incorporated into all institutions. Care and consideration should be given to cultural norms and conventions in expanding creatively by investigating and using caution with boundaries.

\section{Conflicts of Interest}

The author declares no conflicts of interest regarding the publication of this paper.

\section{References}

Antonietti, A., Colombo, B., \& Pizzingrilli, P. (2011). Editorial-Educating Creativity. The Open Education Journal, 4, 34-35. https://doi.org/10.2174/1874920801104010034

Brundrett, M. (2007). Bringing Creativity Back into Primary Education. Education 3-13, 35, 105-107. https://doi.org/10.1080/03004270701311879

Cherry, K. (2016). What Are the Different Theories of Intelligence? Verywell, an About.com brand. https://www.verywell.com/theories-of-intelligence-2795035

Craft, A. (2001). An Analysis of Research and Literature on Creativity in Education. Qualifications and Curriculum Authority.

Davies, D., Jindal-Snape, D., Collier, C., Digby, R., Hay, P., \& Howe, A. (2013). Creative Learning Environments in Education-A Systematic Literature Review. Thinking Skills and Creativity, 8, 80-91. https://doi.org/10.1016/j.tsc.2012.07.004

Gardner, H. (1995). Reflections on Multiple Intelligences. Phi Delta Kappan, 77, 200.

Goleman, D. (1996). Emotional Intelligence. Why It Can Matter More than IQ. Learning, 24, 49-50.

Griffiths, M. (2014). Encouraging Imagination and Creativity in the Teaching Profession. European Educational Research Journal, 13, 117-129. https://doi.org/10.2304/eerj.2014.13.1.117

Hall, C. (2010). Creativity in Recent Educational Discourse in England. World Englishes, 29, 481-492. https://doi.org/10.1111/j.1467-971X.2010.01676.x

Jausovec, N., \& Jausovec, K. (2011). Brain, Creativity, and Education. The Open Educa- 
tion Journal, 4, 50-57. https://doi.org/10.2174/1874920801104010050

Kaplan, D. E. (2017). Online Teacher Training of Cognition and Learning in Education. Psychology, 8, 373-386. https://doi.org/10.4236/psych.2017.83023

Kim, K. H. (2011). The Creativity Crisis: The Decrease in Creative Thinking Scores on the Torrance Tests of Creative Thinking. Creativity Research Journal, 23, 285-295. https://doi.org/10.1080/10400419.2011.627805

Lindstrom, L. (2006). Creativity: What Is It? Can You Assess It? Can It Be Taught? The International Journal of Art and Design Education, 25, 53-66.

Richardson, C., \& Mishra, P. (2018). Learning Environments that Support Student Creativity: Developing the SCALE. Thinking Skills and Creativity, 27, 45-54. https://doi.org/10.1016/j.tsc.2017.11.004

Scott, L., \& Mumford (2004). The Effectiveness of Creativity Training: A Quantitative Review. Creativity Research Journal, 16, 361-388.

Shaheen, R. (2010). Creativity and Education. Creative Education, 1, 166-169. https://doi.org/10.4236/ce.2010.13026

Spendlove, D. (2008). Creativity in Education: A Review. Design and Technology Education: An International Journal, 10, 1360-1431.

Sternberg, R. J. (2006). The Nature of Creativity. Creativity Research Journal, 18, 87-98. http://0-search.ebscohost.com.library.alliant.edu/login.aspx?direct=true\&db=ehh\&AN $=20032012 \&$ site $=$ ehost-live \&scope $=$ site https://doi.org/10.1207/s15326934crj1801_10

Sternberg, R. (1996). Myths, Countermyths, and Truths about Intelligence. Educational Researcher, 25, 11-16. http://0-www.jstor.org.library.alliant.edu/stable/1176335 https://doi.org/10.3102/0013189X025002011

Sternberg, R. J., \& Grigorenko, E. L. (2003). Teaching for Successful Intelligence: Principles, Procedures, and Practices. Journal for the Education of the Gifted, 27, 207-228. https://doi.org/10.1177/016235320302700206

Werry (1949). Creative Education. The Journal of Higher Education, 20, 234-281.

Wise, \& Ferrara (2015). Creativity and Education: Comparing the National Curricula of the States of the European Union and the United Kingdom. British Educational Research Journal, 41, 30-47. https://doi.org/10.1002/berj.3135 